Studia Anglica Posnaniensia 51/3, 2016

doi: 10.1515/stap-2016-0016

\title{
STYLISTIC DEVICES IN THE SCHOOLE OF VERTUE, AN EARLY MODERN MANUAL OF GOOD CONDUCT FOR CHILDREN*
}

\author{
HANNA RUTKOWSKA ${ }^{* *}$ \\ Faculty of English, Adam Mickiewicz University in Poznań
}

\begin{abstract}
This paper is a case study examining the choice and interaction of stylistic devices employed in The Schoole of Vertue, Francis Segar and Robert Crowley's manual of good manners for children issued between 1582 and 1687. It was designed to convince its readers that particular patterns of behaviour were socially beneficial and worth following. In order to enhance the attractiveness, persuasiveness, and mnemonic qualities of the text, several stylistic devices are employed in the manual, including, for example, rhymes, acronyms, as well as binomials. It is generally agreed that repetitive patterns (especially binomials) are typical of formal registers, and particularly plentiful in legal and literary texts in Early Modern English, but the present study shows that similar rhetorical devices were also readily employed in the less formal and elevated style of manuals of good behaviour. Another rhetorical device frequently used in the manual under consideration consists in addressing the reader directly with the second person singular pronoun, especially in imperative constructions, thus creating an ambiance of emotional closeness, characterising the relationship between the master and the pupil.
\end{abstract}

Keywords: Early Modern English, stylistic devices, early modern etiquette manuals, early printed books

* This paper has come into existence as a result of the desire to express my gratitude to Professor Jacek Fisiak, on the occasion of his $80^{\text {th }}$ birthday, for his scholarly mentorship and encouragement in the early years of my career. It touches upon several fields of research and levels of language description, including orthography, phonology, morphology, syntax, lexicon, and semantics, because - given the vast linguistic research interests of the celebrant - it would be difficult and unfair to choose one and only area of research on which to write a commemorative study.

** Faculty of English, Adam Mickiewicz University, al. Niepodległości 4, 61-874 Poznań, Poland, e-mail: rhanna@wa.amu.edu.pl. 
1. Introduction: objectives, corpus, and research methods

The idea that good manners are worth acquiring goes back to antiquity. Already Aristotle emphasised the moral value of good manners (Kristjánsson 2007: 142-143). In England, the first known reference to the importance of civility is ascribed to bishop William of Wykeham, who in the mid-fourteenth century appended the adage "manners makyth man" to his own coat of arms and later made it the motto of New College and Winchester College which he had founded (Griffith 2016). In the Renaissance period, together with the rise of humanism, the revival of interest in antique models and the advent of printing technology, handbooks of good manners started to enjoy unprecedented popularity among readers, as indicated by large numbers of editions and reprints published. The first such handbook of proper conduct printed in England, The book of good maners, itself a translation from French, was issued by William Caxton in 1487 (STC 15394). The rise of interest in manuals of good conduct is certainly also connected with the emergence and development of the middle class in England and makes part of their struggle to ensure cultural legitimacy for their position in the society. Handbooks of good manners remained fashionable throughout the early modern period.

Etiquette manuals were likely to have two main goals. The first was to convince their audience that particular patterns of behaviour were socially beneficial and worth following, and the second to become bestsellers and thus bring income to their publishers, authors and translators. It thus seems logical that the linguistic and extra-linguistic devices employed in such books should contribute to these goals. With this assumption, I have decided to examine the linguistic characteristics employed as stylistic devices in an early modern English handbook. I have chosen for analysis a popular manual of proper conduct for young boys, entitled The Schoole of Vertue (henceforth The Schoole), issued in several editions between 1582 and 1687 by various London publishers. Since linguistic usage changes over time, this study compares the edition published by Henrie Denham in 1582 (STC 22136) with the last edition of this book, issued by George Conyers in 1687 (Wing S2412E), over one hundred years later. Where important differences are found between these two versions, references are also made to other editions of the book. ${ }^{1}$

The Schoole is not homogeneous contentwise. Two thirds are devoted to the manual itself, originally authored by Francis Seager (Segar), and one third is a set of short prayers compiled by Robert Crowley. The first known edition of

According to the English Short Title Catalogue (henceforth ESTC), at least fourteen editions of The Schoole of Vertue were issued, of which twelve are available in the form of facsimiles at Early English Books Online. 
this book, published in 1557 , contains only the manual, whereas all the subsequent editions are supplemented with prayers. The manual part of the following edition, published in 1582, is a considerably modified version of the earlier text. Considering that Segar died in 1563 (as reported in ESTC), the modifications were presumably introduced by Crowley.

The texts under consideration in this study were transcribed from the facsimiles available at Early English Books Online and compiled into an electronic corpus which was then subject to analysis. The two parts of the corpus count 7,760 and 7,538 words, for the editions issued in 1582 and 1687, respectively. As regards research methods, the present contribution is a qualitative and quantitative comparative case study.

The following sections report the findings of an analysis concerning the stylistic devices identified in the texts under consideration, including the editorial changes introduced in the last edition (or earlier). Section 2 introduces some terminology used in the paper, such as genre, text type, register, and style, and relates them to The Schoole. Section 3 discusses visual devices, covering the interaction of typographic and orthographic features. Section 4 is devoted to quantitative and qualitative prosodic features. Section 5 discusses morphological and morphosyntactic aspects, focusing on the use of the second person pronoun, the imperative, the periphrastic DO, and binomials.

\section{Terminology and general characteristics of The Schoole}

The terms genre, text type, register, and style used in the present study require some comment, because their interpretations in literature vary considerably. ${ }^{2}$ The definitions adopted here are based mainly on Diller (1998) and Claridge (2012). Genre refers to text-external considerations: functions, conventional shape and structure of text, e.g., a fairy tale, a letter, and a prayer. Text type is defined by text-internal linguistic criteria, e.g., narrative, expository, and instructive. Register is associated with situational, social, and professional contexts and the domain or field of discourse, e.g., religion, law, and science. Eventually, style comprises the 'characteristic linguistic features of a text' (Diller 1998: 155).

Applying the above definitions to The Schoole, this book contains two genres, a handbook and a prayer, a combination of text type features, including mainly instruction and adhortation, and its register can be classified as representing the domain of education and religion. The style of this compilation of texts is the object of the present study.

$2 \quad$ See Diller (2001) for an overview. 
Nonetheless, the division into genres, text types, and registers is not clear-cut in The Schoole. The manual of good behaviour contains thirteen chapters of advice and instructions, each devoted to some situation in everyday life, but also prayers, including the morning prayer in the introduction, a grace before a meal, and the prayer before going to bed in the last chapter of the manual. It is followed by a four-page long apostrophic poem addressing, in turn, particular social groups, including, e.g., princes, judges, prelates, fathers and mothers, children, masters, and servants.

The instructive elements of The Schoole include the directions on, e.g., how to behave in the street, how to lay the table and how to behave during meals, and how to prepare oneself for school. The titles of the chapters specify the main subject matter discussed in them, e.g., "How to order thy selfe sitting at \# the table" (1582, B2r), "How to behaue thy selfe in talking with anie man" (1582, B6v), "Against the horrible Sin of Swearing" (1687, B4v).

The final part of the book, Crowley's "Certain prayers and graces", contains prayers, displaying intertwined features of different text types, mostly adhortative ones, addressing the readers, e.g., "to God devoutly let us call" (1687, B8v), "Let's now be humble in his sight" (1687, C4v), and "Against no man false witness be" (1687, C2v), but also supplicative, turning to God directly, e.g., "Thy will be done upon the earth, \# like as in Heaven above" $(1687$, C3v), "Bless all that we do drink or eat" (1687, C5r). Moreover, it contains passages expressing gratitude to God indirectly, e.g., "Thanks be to God in heaven above, for he hath fed us well" (1687, C6v), as well as elements of narration, e.g., "The second Table follows then, \# wherein the Lord instructeth us" (1687, C2v).

\section{Visual devices}

The Schoole was published in the relatively small, in octavo format, in this case corresponding to $4 \times 6$ inches. The editions of this book contain few illustrations, but there are several moderately decorative initials. These features imply that it was designed for everyday use and directed to a rather wide target audience. The visual devices employed in The Schoole comprise several elements, which are, to some extent, interrelated.

As regards typography, the first (known) edition of The Schoole was printed almost entirely in blackletter. The Roman typeface is used only for the running

3 Abbreviations A1r, B8v, and the like, provide information on the foliation in the original document, i.e., the capital letter refers to the quire, the number to the leaf, and the lower case letters $r$ and $v$ correspond to the side of the relevant leaf, i.e., the recto and the verso, respectively.

4 The symbol \# marks the beginning of a new line in the source text. 
heads, the initial letter of each chapter, the initials of the author (F.S.), the year of publication (Anno. 1557), and three maxims, one in English, in the title page, and two in Latin, the first of which appears on the verso of the title page (Face aut Tace 'compose or be silent') and the second at the end of the book, immediately before the imprint (Famam virtutis meis \# Abolire nequit 'my reputation for virtue cannot be abolished'). In the second edition, the use of the Roman typeface is extended to the whole title page, the imprint, headings of selected sections (partly in italics), ${ }^{5}$ the Latin abbreviation for 'chapter' (e.g., Cap. 5.) and the proper names referred to throughout the book (e.g., Cato, Cicero, Aristotle, Isocrates). In 1593 (and all the following editions), the use of Roman typeface is further extended to the headings of all the chapters and sections. Apart from changes in the kind of typeface, printers varied also the sizes of type used. The variation in the typeface size is particularly salient in the title page of most editions (see Figure 1). The title itself is remarkably elaborate, covering approximately four fifths of the whole title page (which is not unusual in early modern books). The remaining part of the page is devoted to a short maxim and the imprint.

The typographic features of the book interact with the orthographic ones. The best example of such interaction is in acrostic poems. In the 1557 edition one acrostic is recorded, presenting the surname of the author, Seager. In the following edition, compiled by Crowley in 1582, three acrostic poems appear, all on the second page of the book (A1v). The first and also the most elaborate one contains the name of the compiler (see Figure 2), ${ }^{6}$ and there are also two shorter poems on the same page, one with the name of Seager, which is a modified version of the original poem (see Figure 3), and the other with the name of the printer (Henrie Denham, see Figure 4). All the remaining editions preserve the acrostic poems for the compiler and for the author, but omit the one for the printer.

5 Italics seem to have started appearing in books printed in England in the 1580s. Rutkowska (2013: 83) reports their introduction in the 1585 edition of the Kalender of Shepherdes.

6 Figures 2-4 contain the font imitating blackletter used in the original documents. It has been designed by Maciej Ulatowski and is used here for illustrative purposes. It has been inspired by the blackletter fonts discussed in Stribley (1987: 60-63) and Bringhurst (2008: 266-68), as well as the typefaces used by the early modern printers of The Schoole editions, but it does not contain a reproduction of any particular images from these sources. 
Figure 1. The title page layout of the 1687 edition of The Schoole (a simulation)

\begin{tabular}{c} 
T H E \\
S C H O O L \\
O F \\
V E R T U E . \\
A N D \\
Book of Good Nurture; \\
teaching Children and Youth \\
their Duties. \\
Newly perufed, corrected and amended. \\
Hereunto is added \\
A brief Declaration of the \\
Duties of Each Degree \\
A L S O \\
Certain Prayers and Graces: \\
Compiled by R. C. \\
\hline $\begin{array}{c}\text { If thou wilt be counted virtuous and holy, } \\
\text { Despise not good counfel, but rebuke folly. }\end{array}$ \\
\hline London, Printed for M. W. and George Conyers, at the \\
Sign of the Golden-Ring upon Ludgate-Hill, over \\
against the Old-Baily. 1687.
\end{tabular}


Figure 2. Crowley's acrostic poem (1582, A1v)

The Preachers counsell to

Parents \& Tutors.

RE్

O parents, of pour childzen deere;

Bee bnto them of faith and trutb

Eramples manifeft and cleere:

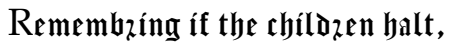

The tutors chífflíe are in falt.

C.Dntrall them wifelie with the toong,

$\operatorname{Ref}_{\mathfrak{r}} \mathfrak{z}_{\mathrm{me}}$ them alfo with the rod;

Out of their barts, whiles they be poond,

Werde all abufe of fending 5 ad:

Let bice in them haue fmall abod,

Erhozat, cozrect, and repzehend

Your childzen, that they may amend.

The modifications of Seager's acrostic in the 1582 edition were quite substantial, including not only the introduction of punctuation, but also a few reformulations. Namely, "I shall find fauour" replaced "I doubt not fauour", "that doo me blame" is used instead "For it me blame", and "whom I shall offend \# Rightlie to read me, \# \& their faults t'amend" supplanted "It shall offende \# Reade and then iudge \# Where faulte is amende". The changes in the subsequent editions affect mainly spelling. Additionally, them forgiue is reordered to forgiue them in 1621 (forgive them from 1660). In the same edition, shall is omitted in the tenth half-line, and amend replaces t'amend. By contrast, Crowley's acrostic was subject to few modifications in the subsequent editions, apart from orthographic changes. ${ }^{7}$ The only grammatical change is from the form remembring in the fifth line in 1582 to the imperative remember in 1593 (and the other editions), and from correct in the penultimate line in 1582 to reproue in 1626 (reprove from 1660).

7 Only selective orthographic features are discussed here. For more details concerning the orthographic characteristics of The Schoole editions, see Rutkowska (2016). 
Figure 3. Seager's acrostic poem (1582, A1v)

The Authors name

in verdict.

Sấie well fome will, by thís my labour,

Eurríe man yet

will not faíe the fame:

Almong the good,

J lball fínd fauour,

Wod them fozgíue

that doo me blame.

Eth man $\mathfrak{J}$ wifl whom $\mathfrak{J}$ fhall of fend,

zhíghtlíe to read me, ft their faults t'amend

The third acrostic is as short as Seager's, but presents both the first name and the surname of the printer. The odd half-lines start with the letters forming Henrie, and the first letters of the indented even half-lines read Denham.

Figure 4. Denham's acrostic poem (1582, A1v)

The Printer to youth

in generall.

liąndocmooth this booke,

Dere child learne at large:

Expzeffíng plainlíe

$\mathbb{E}_{\mathfrak{c h}}$ point of thy charge:

IReglect not inftruction,

IRofíe that is naught:

Remember, J jzate thee,

ląerein whbat is taught:

In pouth to be ruled, 


\section{Alnd fchooled up well: \\ Experíence declareth, \\ Moft things doth errell.}

It can be assumed that all the typographic and orthographic features discussed in this section as well as their modifications, including the introduction of new typefaces, their combinations in specific parts of The Schoole, and the changes in the layout, especially of the title page, aimed at the enhancement of the readability of the book as well as of its visual attractiveness as a sellable product in order to draw the attention of a potential buyer.

\section{Quantitative and qualitative prosody}

The Schoole is composed almost entirely in verse, and it is possible to identify several prosodic features in this book, associated mainly with rhythm and rhyme. In the acrostic poems, the dominant pattern is the iambic tetrameter, though it is not always carefully observed. Its characteristics comprise a sequence of four iambic feet as, for example, in "Regard the soft and tender youth" (1582, A1v), where I have indicated the stressed syllables in bold. Crowley's opening poem contains two stanzas. The first one can be classified as a sestet with the a-b-a-b-c-c rhyme sequence, and the second contains seven lines, with the d-e-d-e-e-f-f scheme. Apparently, the number of letters in Crowley's surname necessitated the insertion of the extra 'e' rhyme in the fifth line of the second stanza. The other two acrostics are shorter. Typographically, they contain twelve lines each, but prosodically, they can be treated as half lines, and thus as sestets, e.g., "God them forgeue \# for it me blame" (1557, A1v). Seager's poem has an a-b-a-b-c-c rhyme scheme, whereas Denham's has the rhymes arranged in three couplets (a-a-b-b-c-c). The rhymes in Crowley's and Denham's acrostics are nearly always single (masculine), e.g., youth truth, large $\sim$ charge. In Seager's acrostic two rhymes are masculine (same blame and offend $\sim$ amend) and one is feminine (labour $\sim$ fauour).

The remaining part of the manual occurs in couplets, with the a-a-b-b-c-c-d-d... rhyme scheme. Four stresses per line are generally preserved, but the number of unstressed syllables varies. For instance, example 1 shows that a stressed syllable can be accompanied by one, two or three unstressed syllables. In the 1582 edition, the lines are usually divided typographically into half-lines (see example 2). By contrast, such layout is recorded nearly exclusively in the introduction and the first chapter $(\mathrm{A} 3 \mathrm{r}-\mathrm{A} 5 \mathrm{v})$ as well as a four-page long poem on "The particular Duties of all Degrees" (B6v-B8r) in the last edition. 
1) O Little Children, eschew each ill game, for that hath brought many a one unto shame As dicing, and carding, with such other plays, these have undone many we see now adays $(1687, \mathrm{~B} 2 \mathrm{r})$

2) FLy ever sloath and overmuch sleep, In health thy body thereby thou shalt keep. (1687, A4r)

In the set of prayers added to the manual by Crowley, the first half of the text is arranged into quatrains $(1582, \mathrm{C} 7 \mathrm{v}-\mathrm{D} 4 \mathrm{r}$ and $1687, \mathrm{~B} 8 \mathrm{v}-\mathrm{C} 4 \mathrm{v})$ with alternating rhymes (a-b-a-b c-d-c-d...). The boundaries between stanzas are usually (not always) indicated typographically by the insertion of blank lines to divide them. Then follow two prayers (1582, D4v-D5r and 1687, C5r-C5v) with four stanzas of seven lines (a tercet and two couplets) each and the rhymes following the pattern a-b-a-b-b-c-c d-e-d-e-e-f-f etc.

Most rhymes in the prayers are masculine, like in the rest of the book. They are normally exact, with one exception, namely King been (1687, C5r), which replaced the earlier Queene $\sim$ beene $(1582, \mathrm{D} 4 \mathrm{v})$. This modification was first introduced in the 1621 (C5r) edition of The Schoole and was evidently due to the change of the monarch from Queen Elizabeth to James I. Interestingly, although the last edition (1687) was published already during the reign of James II, it still contains the reference to King Charles II (example 3).

3) O Lord preserve in health and peace

King Charles, our most gracious King,

Thy holy Spirit in him increase, That he may be as he hath been.

$(1687, \mathrm{C} 5 \mathrm{r})$

This example shows that particular versions of The Schoole were not always carefully read and edited before publishing. In this case, the compositor evidently followed directly the relevant passage in the previous edition of the book $(1677, \mathrm{C} 5 \mathrm{r})$.

Because the time which elapsed between the first and the last edition of The Schoole exceeds one hundred years, it can be assumed that some of the rhymes in the later editions were not functioning properly any more and had become mere visual rhymes. This definitely applies to the rhymes in examples 4 and 5 . 
In the former example, soon must have contained /us/, but by the $1680 \mathrm{~s}$, the Middle English /o:/ in done had supposedly undergone not only the raising to $/ \mathrm{u} /$, but also the shortening to $/ \mathrm{u} /$ and the unrounding to $/ \Lambda /$. In the latter example, by 1687 , the Middle English / $\varepsilon$ : in lead is likely to have got close to /is/, whereas the vowel in tread must have become shortened to $/ \varepsilon /$.

4) With possible speed then haste thou right soon,

if need so require, that so it were done. $(1687, \mathrm{~B} 3 \mathrm{r})$

5) Let reason thee rule, and not wit thee lead, in following thy fancy a wrong way to tread. $(1687, \mathrm{~B} 2 \mathrm{r})$

Such obsolete rhymes could have been one of the reasons why that this was the last edition of The Schoole. A new edition of this book in the end of the seventeenth century or the beginning of the eighteenth century would require reinventing numerous rhymes in order to retain the attractiveness of the book.

In the prayer part of the book, one line generally contains four stresses, but there are also five poems displaying the metre typical of ballads and hymns. It consists of alternating tetrameters and trimeters with the rhymes falling on the latter, as in example 6, based on Our Father.

6) Giue vs this daie our dailie bread,

Which need dooth cause vs craue:

For why, our soules and bodies both, Of thee their food must haue.

$(1582, \mathrm{D} 3 \mathrm{r})$

In the 1582 edition (D2v), this hymn is additionally accompanied with musical notation in the form of a set of neumes placed on the stave, which implies that it was designed for being sung or played on some instrument. The other four poems with the ballad metre comprise two graces to be said before a meal and two after a meal (1582, D5v-D6r and 1687, C6r-C6v). The book ends with a set of short prayers in prose, graces before and after a meal as well as prayers for the monarch and the realm, six in the 1582 edition (D6v-D7r) and five in the 1687 one $(\mathrm{C} 7 \mathrm{r}-\mathrm{C} 7 \mathrm{v})$.

As regards the stylistic function of the prosodic characteristics, especially the stress and rhyme schemes in The Schoole, it can be assumed that the alternation of patterns was supposed to raise the attractiveness of the book. It is possible that this book was designed for reading aloud to children in the classroom, so the prosodic features can be considered as auditory devices. Presumably, the presence of rhymes and metrical devices of different types was likely to appeal to the young audience more than a plain text in prose. 
5. Morphology and morphosyntax

A linguistic analysis of The Schoole editions reveals a set of four main morphological and morphosyntactic features characteristic of linguistic usage in this book. They include the heavy occurrence of the second person singular pronoun forms, the imperative, the periphrastic DO, and binomials.

\subsection{Number and case distinction in the second person pronoun}

The pronominal system underwent considerable changes in Middle English and Early Modern English, especially with regard to the second person. As conveniently summarised in Lutz (1998: 191), the most important developments include the use of the originally plural forms for politely addressing individuals of higher rank from the thirteenth century onwards, the generalisation of the plural forms for addressing individuals in Early Modern English, as well as the spread and establishment of the plural object form you as the only form of direct address, also in Early Modern English.

Although these changes must have been well advanced by the end of the sixteenth century, the second person pronoun in the manual is represented mainly by the singular forms. Table 1 presents the distribution of pronominal forms in the second person. It provides the numbers of tokens in two formats, as absolute values and, within brackets, as standardised ones (per 10,000 words). Particularly frequent are the possessive forms of the pronoun, with 221.6 tokens (per 10,000 words) in 1582 and 209.6 in 1687, which account for over $50 \%$ of occurrences in the singular number. The subject forms, with 118.6 tokens in 1582 and 122.0 in 1687 , cover approximately $30 \%$ of the occurrences. By comparison, Moessner (2012: 704) gives the values 17.6 and 12.2 as the average occurrences (per 10,000 words) of thou in the Helsinki Corpus, in the periods 1570-1640 and 1640-1710, respectively. This means that the second person singular pronoun occurs 7-10 times more often in The Schoole than it does on average in English in the relevant periods in which the editions were published.

Table 1. The second person pronoun singular forms in The Schoole

\begin{tabular}{lrr}
\hline & 1582 & 1687 \\
\hline thou & $92(118.6)$ & $92(122.0)$ \\
thee & $56(72.2)$ & $55(73.0)$ \\
thy/thine & $172(221.6)$ & $158(209.6)$ \\
\hline
\end{tabular}


The singular forms of the second pronoun are indeed virtually ubiquitous in the manual. Example 7 gives some idea of the frequency with which they are recorded. This example also shows clear case distinction, with thou functioning as the subject, thee as the object, and thy/thine as the possessive modifier. The two possessive variants are still in complementary distribution in The Schoole, occurring before a noun starting with a consonant or a vowel, respectively. This principle is fully observed in the 1582 edition, where nine tokens of thine in the attributive function are recorded, but apparently loses its strength over time, as only three instances of attributive thine are found in the last edition, the other having been replaced with thy and the definite article.

7) Thy hands see thou wash,

thy head likewise keame:

And of thine apparell, see torne be no seame.

With thy cap fairelie brusht, thy head couer than, Putting it off, in speaking to anie man. Cato doth counsell thee, thine elders to reuerence $(1582, \mathrm{~A} 4 \mathrm{v})$

The singular second person pronoun is mostly used in the manual part of The Schoole, which is designed like a sequence of lessons given by the speaker, who takes on the role of a tutor, where he (or she) targets directly the reader, that is a young pupil, as illustrated in example 7 . In this and similar cases, the singular forms mark the difference in social status between an adult and a child, where the former is superior to the latter. Such forms are also recorded in a different context, namely in prayers, when the speaker addresses God (see examples 8 10). Nonetheless, in this situation, accounting for $13.4 \%$ tokens of the second person singular pronoun in 1582 and $12 \%$ in 1687, the singular expresses intimacy between God and the believer, and follows biblical conventions rather than showing the lack of reverence towards divinity.

8) O Lord, thou giuest them meat in due season $(1582$, D6v)

9) To thee be praise, O Father deere (1582, D5v)

10) thou openest thy hand, and fillest with thy blessing every living creature $(1687, \mathrm{C} 7 \mathrm{r})$ 
It is noteworthy that the total number of thou and thee instances virtually does not change over time, even though numerous passages in The Schoole undergo reformulation over time. The pairs of examples 11-12, 13-14, and 15-16 illustrate the types of modifications introduced in the manual, including the omission of the pronoun, its introduction where it was not present before, and change in word order.

11) At hand be thou readie, if anie doo call $(1582, \mathrm{~B} 1 \mathrm{r})$

12) At hand be ready if any do call $(1687, \mathrm{~A} 7 \mathrm{v})$

13) Wine to them fill, or else Ale or Beere (1582, B1v)

14) Wine see thou fill then, or else Ale or Beer (1687, A8r)

15) Be thou thy selfe iudge, hauing wisdome $(1582, \mathrm{~B} 7 \mathrm{v})$

16) Be thy own judge, thou having wisdom (1687, B3r)

By contrast to thoulthee, the possessive thy becomes less popular in 1687 than in 1582, although it also replaces thine in a few passages. This is mainly because thy itself occasionally gives way to the definite article (cp. examples 17 and 18) or is omitted (cp. examples 19 and 20).

17) Downe from thy chamber, when as thou shalt go (1582, A4r)

18) Downe from the Chamber, when as thou shalt go $(1687, \mathrm{~A} 4 \mathrm{r})$

19) For these are things for thy studie necessarie $(1582, \mathrm{~A} 5 \mathrm{r})$

20) For these are things for study necessary $(1687$, A5r)

The high frequency of the second person pronoun singular tokens in The Schoole does not mean that plural is not used there at all. Table 2 provides the numbers of plural tokens of the second person pronoun. They constitute 21$22 \%$ of all the second person tokens in this book. They occur in the passages where children are addressed collectively, but also where the speaker addresses 
adults, that is in the apostrophic poem directed to people of different social groups, as well as in three prayers, and in Crowley's acrostic.

Table 2. The second person pronoun plural forms in The Schoole

\begin{tabular}{lrr} 
& 1582 & 1687 \\
\hline ye & $35(45.1)$ & $24(31.8)$ \\
you & $25(32.2)$ & $29(38.5)$ \\
your & $29(37.4)$ & $29(38.5)$ \\
\hline
\end{tabular}

Example 21 illustrates one of several switches between the singular and plural forms when the 'tutor' is addressing one child or children as a group, alternatively. Obviously, thy and thou are unequivocally singular forms. However, the presence of the passage "one with another" makes it clear that you refers to more than one addressee here. The speaker switches from the singular to the plural and back again at least four times in the manual. From the stylistic point of view, the switches between the singular and the plural are likely to have been employed in order to break the monotony of usage and to more effectively hold the attention of the young reader or, rather, the listener (assuming that the manual could have been read aloud to children).

21) In the Church comelie, thy selfe doo behaue:

Sober in vsage, in countenance graue. While you be there, talke of no matter:

Nor one with another

whisper nor chatter.

Order thy selfe,

reuerentlie alwaie:

When to the Church,

thou shalt come to praie.

(1582, B5r)

22) IN going by the way, and passing the street, Thy cap put off, salute those ye meet (1582, A5v) 
The number distinction between the singular and the plural is generally observed throughout The Schoole. There are, nevertheless, some cases which could, alternatively, be interpreted as slips towards the presumably neutral or polite second person forms when addresing one child. In example 22, ye occurs where thou would rather be expected (cp. thy in the preceding line). It was copied in the editions issued between 1593 and 1635. In 1640, the form ye was replaced with you, but it reappeared in 1660, only to be again displaced by you in 1670. This discontinuity of usage can be explained if one assumes that the compositor of the 1660 used the 1635 (or earlier) edition as the copy-text. Analogically, the model followed by the worker setting the type for the 1670 edition could have been a copy of the 1640 version of the book. Interestingly, you must have been considered a mistake in this context in 1677, because it was corrected to thou, which was then copied in the last edition. Alternatively, ye could also be interpreted as a plural form in example 22, but there is no evidence for such interpretation in the text itself. There are seven other instances of such equivocal use of ye/you in the 1582 edition of the manual, and eight in 1687.

23) When ye haue done remember those, which want and stand in need $(1582, \mathrm{D} 5 \mathrm{v})$

24) When you have done remember those which want and stand in need (1687, C6r)

25) The common prouerbe, remember ye ought: Better to be vnfed, than to be vntaught. $(1582, \mathrm{~B} 7 \mathrm{v})$

26) The common proverb remember yet oft, better to be unfed, than unmannerly taught. (1687, B3r)

As regards the exponents of the grammatical category of case, the distinction between the subject and the object is strong in the singular (see examples 7-9), but in the plural the form you is in the process of replacing the ye in the subject function (cp. examples 23 and 24). This development is also visible in Table 2, where the number of ye tokens decreases between 1582 and 1687, whereas the number of you tokens increases. Yet, the increase and decrease values are not 
equal. Eleven instances of ye are lost between these years, but only four instances of you are gained. This difference is a result of editorial reformulation of certain passages, which sometimes involves the omission of the pronoun (cp. examples 25 and 26). The progress of the generalisation of you as the only form of address is evident in its share in the total number of subject instances of YOU, which moves from $34 \%$ in 1582 to $52 \%$ in 1687 .

\subsection{Verbal constructions}

This section is devoted to the most characteristic verbal constructions in The Schoole, that is the imperative and the subjunctive (both inflectional and periphrastic), with particular attention paid to clauses containing the second person pronoun. Further on, constructions with the periphrastic DO and those with binomials are considered. The analysis shows certain strong preferences on the part of the author of the manual concerning morphosyntactic choices, which are likely to have been determined by the search for stylistic effects.

\subsubsection{Moods}

Constructions in the imperative mood permeate the whole book under analysis and definitely constitute one of its most conspicuous stylistic features, although the other moods are also represented in the corpus. The imperative structures can be found in the majority of examples quoted in the previous sections, especially in the acrostic poems by Crowley and Denham in Figures 2 and 3. Due to the pervasiveness of the second person pronoun in The Schoole, the attention in this subsection is focused primarily on the form and mood of the verb which accompanies a pronoun subject.

The subject pronoun form in the singular is always in concord with a verb in the indicative mood and with a modal, which is indicated by the preservation of the inflectional endings $\{-\mathrm{st}\}$ and $\{-\mathrm{t}\}$, for example, thou maist, thou shalt, and thou dost. In contrast, the plural pronoun form is followed by an unmarked verb form, as in ye may, you shall, and ye do. 
Figure 5. Clauses with the second person pronoun subject in The Schoole

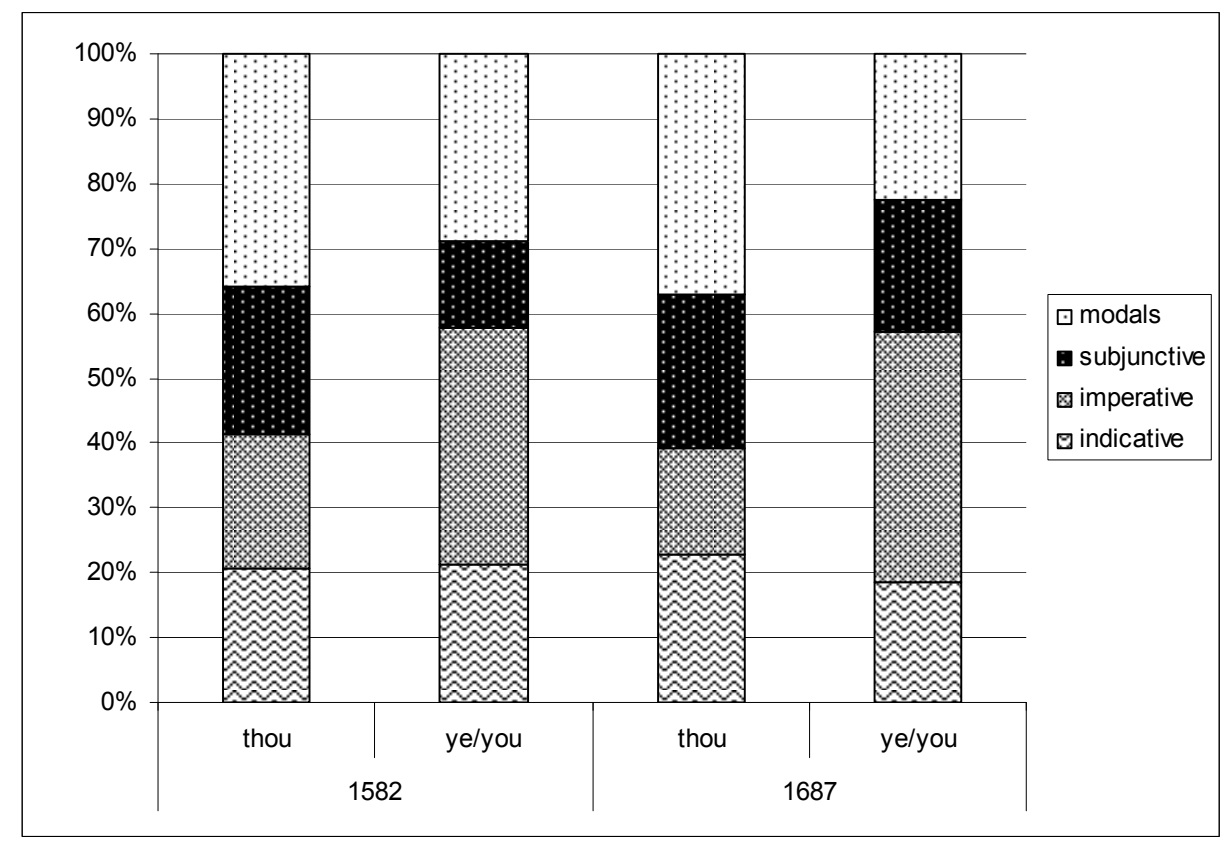

In the corpus, the second person pronoun is recorded in constructions in all the moods. Figure 5 presents their proportions. They depend on whether the pronoun is in the singular or in the plural number, and to a lesser extent, when the book was published. Thou is recorded mainly in clauses with modal verbs, yielding $35.9 \%$ and $37 \%$ in 1582 and 1687 , while for ye/you the corresponding values are lower, reaching $28.8 \%$ and $22.4 \%$ in the respective editions. This drop is mainly due to reformulations in the later edition, leading to the omission of the pronoun altogether or, occasionally, to the replacement with thou. Simultaneously, one can see a considerable rise in the percentage of subjunctive clauses with yelyou from $13.5 \%$ to $20.4 \%$. This change is caused by the substitution of thou with you, and occasionally the rise of the plural pronoun where it had not been recorded before (cp. examples 27 and 28). In fact, replacements in both editions of The Schoole are recorded in both directions, from yelyou to thou, and from thou and yelyou, depending on the editor's whim.

27) If occasion of laughter, at the table thou see:

Beware out of measure, at no hand to bee.

$(1582, \mathrm{~B} 3 \mathrm{v})$ 
28) If occasion of laughter at the table you see, beware out of measure at no hand you be.

$(1687, \mathrm{~B} 1 \mathrm{r})$

On the whole, the structures expressing modality, including both the inflectional and periphrastic subjunctive, account for $58.7 \%$ and $60.9 \%$ of clauses with the singular subject thou, in 1582 and 1687, respectively. The percentages of subjunctive clauses (of both types) are considerably lower for ye/you in the role of the subject, reaching $42.3-42.9 \%$. The modals in clauses containing thou express mostly obligation (67-70\%, depending on the edition), with shalt itself covering $57-62 \%$ of the tokens, and must and oughtest $8-10 \%$. By comparison, in the clauses with ye/you obligation-related modals (shall, should, must, ought) constitute only $45-47 \%$. In turn, the plural subject pronoun in the second person occurs more often with the verbs in the imperative, which cover $36.5 \%$ and $38.8 \%$ of clauses in the respective editions, whereas only $20.7 \%$ (in 1582) and $16.3 \%$ (in 1687) of the instances of the singular subject occur in this type of clause. The decrease in the latter case is caused by the occasional omission of the pronoun in the imperative clause (cp. examples 29 and 30). It must be remembered, though, that the clauses in the imperative mood containing a pronoun subject constitute only one tenth of all the imperative constructions in The Schoole, as the subject in such cases is not obligatory and, apparently, receding.

29) At hand be thou readie, if anie doo call, To fetch or take vp, if ought chance to fall. $(1582, \mathrm{~B} 1 \mathrm{r})$

30) At hand be ready if any do call, to fetch or take up if ought chance to fall. $(1687, \mathrm{~A} 7 \mathrm{v})$

Considering the fact that the indicative mood is the default one in English, independent of the period, its share among the clauses with the second person pronoun subject in The Schoole editions can be judged as markedly low, especially as regards the singular pronoun subject forms, which occur with the verbs in the indicative only in $20.6 \%$ of the instances in 1582 and in $22.8 \%$ in 1687. The percentage is slightly higher for the indicative verbs with the plural subject pronoun, reaching $30 \%$ in 1582 and $34 \%$ in 1687, but still remains at a low level. Presumably, the unusually high share of the clauses in the subjunctive and in the imperative is connected with the functions of the genres, 
i.e., the manual and the prayer, represented in The Schoole, characterised by the dominance of exhortative, adhortative, and instructive text type features.

The adhortative and exhortative character of the book under consideration is further strengthened by the occurrence of numerous instances of the so called first person imperative, as in "Our wills to his word now let us frame" (1687, B1v), and third person imperative, "Let not thy tongue, \# at the table walke" (1582, B2v; see also the antepenultimate line in Figure 2 as well as example 5), both with the verb LET, amounting collectively to 25 (32.2 per 10,000 words) in 1582 and 27 (35.8) in 1687. The former construction occurs mainly in the prayers, and the latter in the main (manual) part of the book.

\subsubsection{The uses of DO}

Another characteristic feature of The Schoole is the high frequency of clauses containing the the verb DO. Although it is recorded in a variety of morphosyntactic contexts, it most often occurs in periphrastic affirmative statements, as in examples 31 and 32, as well as in Figure 3 (that doo me blame) and Figure 4 (Most things doth excell) in section 3. This usage accounts for $75.5 \%$ of all the 74 tokens of DO in each edition (see Table 3 and Figure 6). In most instances, DO in affirmative clauses, where it is optional in grammatical terms, has a prosodic (rhythmic) role to play, because its addition ensures the required number of syllables in a given line.

31) First in the Morning when thou dooest awake (1582, A4v)

32) Cato doth counsell thee (1687, A4v)

The periphrastic DO can also be found in positive imperatives (examples 33 and 34 ), but these account for merely $9.5-12.2 \%$ of all the tokens.

33) Ech side of the cloth, doo thou turne in $(1582, \mathrm{~B} 1 \mathrm{v})$

34) use but few words \& thy tongue do thou charm (1687, A6v) 
Table 3. The uses of DO in The Schoole

\begin{tabular}{lrr}
\hline & 1582 & 1687 \\
\hline affirmative & $74(95.4)$ & $74(98.2)$ \\
lexical & $9(11.6)$ & $7(9.3)$ \\
imperative & $7(9.0)$ & $9(11.9)$ \\
negative & $5(6.4)$ & $5(6.6)$ \\
substitutive & $3(3.9)$ & $3(4.0)$ \\
$\quad$ total & $98(126.3)$ & $98(130.0)$ \\
\hline
\end{tabular}

Figure 6. The uses of DO in The Schoole in percentages

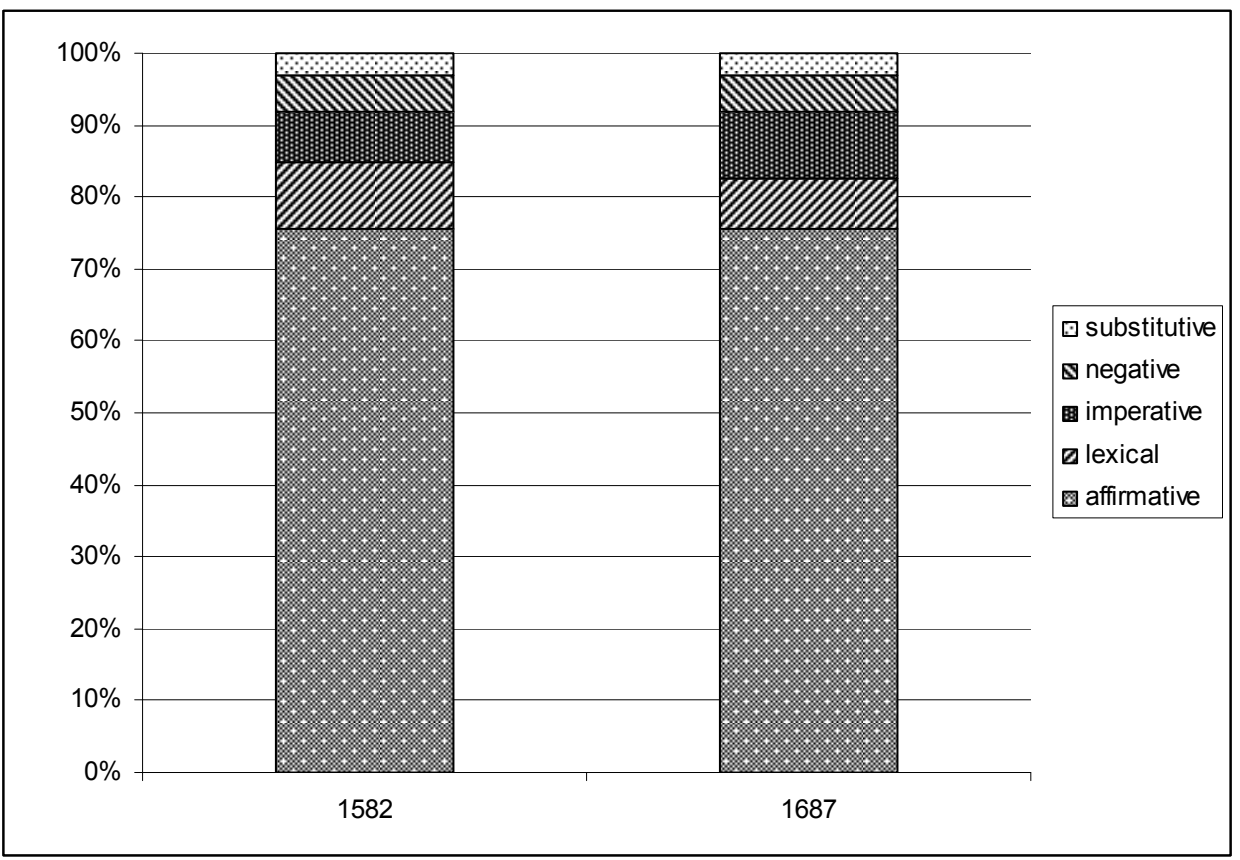

Occasionally DO takes the role of a lexical verb, with a general factitive meaning, e.g., "If it shall mooue thee, to doo that is ill" (1582, B6r), or a substitutive verb, as in example 35. It rarely functions as an auxiliary, and does it only in negative imperatives, in clauses with (example 36) or without the pronoun subject (example 37). As a rule, though, negation is expressed without the auxiliary DO in The Schoole, by placing the particle not after the verb. 
35) Else maist thou happen thy seruice to spill, Upon thine apparell, or else on the cloth: Which for to doo would anger them both $(1582, \mathrm{~B} 1 \mathrm{r})$

36) Doo not thou vs to triall bring (1582, D3r)

37) Thy Spoon with pottage too full do not fill (1687, A8v)

According to Rissanen (1999: 240), "the periphrasis has always been favoured in discourse situations more typical of speech than of writing". Apparently, the frequent use of periphrastic DO in The Schoole, contributes to the impression of the oral-like nature of the tutor's instructions in this book and as such can be considered a powerful stylistic device. In some statements, one can interpret DO as being added for emphasis, but even when this is uncertain, its general frequency is what counts, because, as Rissanen (1999: 240) further states, "do in itself is not necessarily emphatic, but it adds to the intensity and emphasis of the utterance".

5.3. Binomials: The interface of syntax, lexicon, and semantics

Apart from the features discussed so far, The Schoole is also characterised by parallel structures and repetitive patterns of various length, some of which are maxims. Examples 38-41 illustrate such constructions at the sentence level.

38) Uertue to followe, and vice to eschue Here this our request, and grant our desire (1582, A3r)

39) It dulleth the wit, and hurteth the braine $(1582, \mathrm{~A} 4 \mathrm{r})$

40) Not smacking thy lips as commonly do Hogs, nor gnawing of Bones as do Dunghill dogs $(1687, \mathrm{~A} 8 \mathrm{v})$

41) Not live to eat, but eat to live, and live to praise the Lord (1687, C6v)

A special case of structural parallelism in the corpus under analysis, at the level of phrase, are binomials. Clear examples of these can be spotted already in the first lines of Crowley's acrostic poem (Figure 2). Further instances are illustrated in examples 42-43. Binomials usually consist of two semantically related words belonging to the same word class, coordinated by a conjunction, 
such as and or or (Malkiel 1959, Bhatia 1994). ${ }^{8}$ When extended to a longer sequence, they can be referred to as multinomials (approximately one tenth of the tokens in the corpus), as in examples 44-45. These last two examples illustrate also the alliteration of some components, which is occasionally employed by the authors of The Schoole. The counts offered in this study include also these instances of binomials where the head components are accompanied by determiners and modifiers, as in examples 46 and 47 .

42) We ought not to reckon and count the thing hard That bringeth pleasure and joy afterward. $(1687, \mathrm{~A} 5 \mathrm{v})$

43) To him thy sinnes shew and confesse:

Asking for them, grace and forgiuenesse. $(1582, \mathrm{~B} 4 \mathrm{r})$

44) That thou take with thee pen, paper, and inke (1582, A5r)

45) For Food will not see you perish, but will you feed, foster and cherish. (1687, A7r)

46) This done, thy satchell and thy bookes take (1582, A5r)

\section{7) Be free of a Cap and frank of a Knee (1687, A6v)}

Binomial structures are typical features of formal registers in Early Modern English (Nevalainen 1999: 382-383), particularly of literary language (Adamson 1999: 559) and of legal texts (Bhatia 1994: 142-144, Kopaczyk 2013). The Schoole does display some literary features such as, for example, rhymes and particular stress patterns, so it can be considered as representing applied literature, understood as literature for educational purposes.

8 Consult also Kopaczyk \& Sauer (forthcoming) for an overview of existing definitions and approaches to binomials. 
Table 4. The types of coordinators in binomials in The Schoole

\begin{tabular}{|c|c|c|c|c|}
\hline & & 1582 & & 1687 \\
\hline AND & $159(204.9)$ & $82.8 \%$ & $152(201.6)$ & $84.0 \%$ \\
\hline OR & $26(33.5)$ & $13.5 \%$ & $19(25.2)$ & $10.5 \%$ \\
\hline NOR & $7(9.0)$ & $3.7 \%$ & $10(13.3)$ & $5.5 \%$ \\
\hline total & $192(247.4)$ & $100 \%$ & $181(240.1)$ & $100 \%$ \\
\hline
\end{tabular}

Table 4 presents the information on the types of conjunctions joining the elements in such constructions as well as on the general frequency of binomials in The Schoole. As expected, ${ }^{9}$ AND is the most common coordinator in the relevant phrases, accounting for $82.8-84 \%$ of all the tokens, followed by OR, covering $10.5-13.5 \%$ and NOR, with $3.7-5.5 \%$. Interestingly, the proportions between binomials containing particular conjunctions and the number of binomial phrases in general resemble the situation recorded in a different, completely unrelated Early Modern English text, the Kalender of Shepherdes, discussed in Rutkowska (forthcoming). This implies that binomials could have been a ubiquitous feature of various text types and genres in Renaissance English.

As regards word classes, binomials in the corpus are mainly nouns $(62.5 \%)$. Verbs cover $24.0-24.3 \%$ of the tokens, adjectives $11.0-11.4 \%$, and adverbs 2.1-2.2\%. As Figure 7 indicates, the differences between the editions in this respect are minimal. The percentage of nouns seems rather stable in various genres and text types (see, e.g., Gustafsson 1984: 132; Mollin 2013: 173; Kopaczyk 2013: 190, 207), but those of verbs and adjectives may vary (compare, e.g., the studies in Kopaczyk \& Sauer, forthcoming). The share of verbs in The Schoole is relatively high, and seems to correspond to the adhortative nature of this book. In more descriptive texts, adjectives can dominate (see, e.g., Rutkowska, forthcoming).

$9 \quad$ Other studies report similar proportions of coordinators; see, e.g., Mollin (2012: 83). 
Figure 7. Binomials in The Schoole according to word class (percentages)

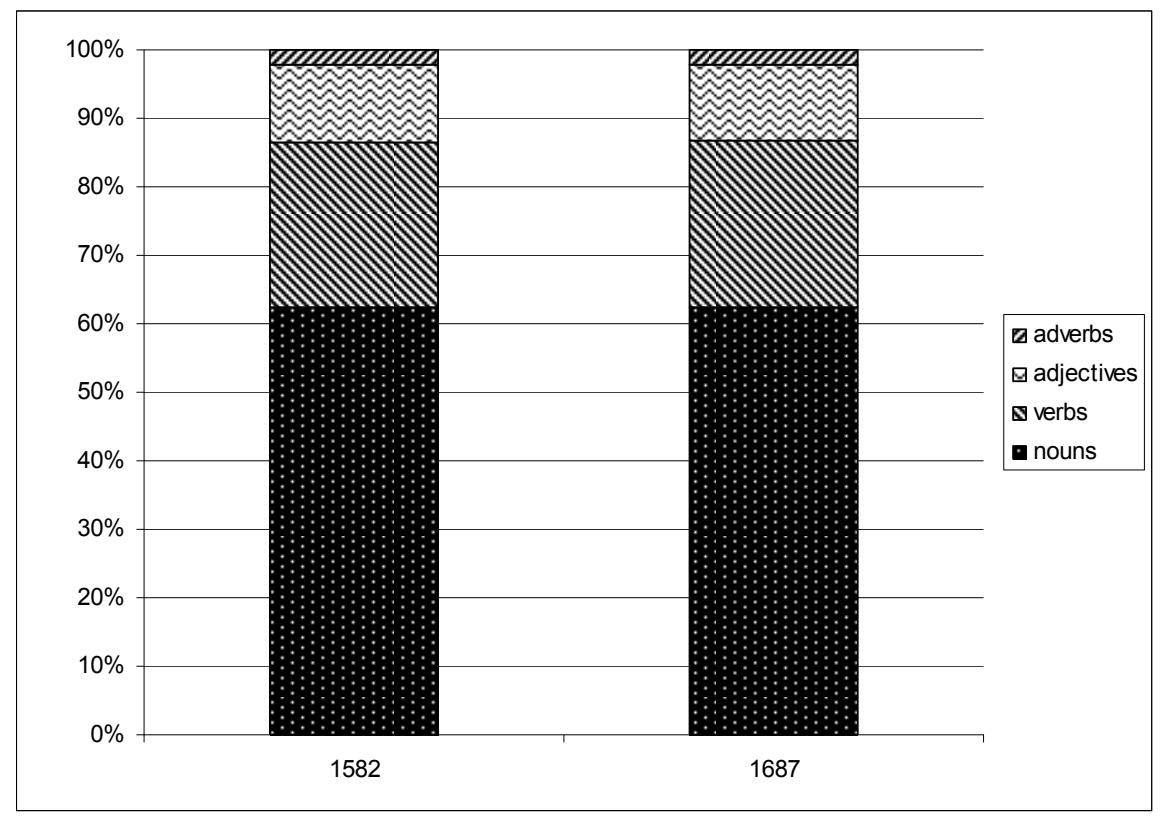

The semantic relationships between the components in the binomials in The Schoole can be divided into synonymy (example 48), antonymy (example 49), and contiguity (examples 50 and 51). The last of these categories is a blanket term, which comprises "various degrees of hyponymy/hyperonymy" as well as "sequential and causal relationships" (Kopaczyk \& Sauer, forthcoming). Binomial phrases with synonymous components, also known as binomials proper (see, e.g., Kopaczyk 2009, 2013: 188), cover 32.3\% of the tokens in 1582 and $30.9 \%$ in 1687 , antonyms constitute $13.5 \%$ and $14.9 \%$ in respective editions, and the remaining $54.2 \%$ and $54.1 \%$ are instances of contiguity. Figure 8 presents the proportions of semantic categories among binomials in the corpus.

48) It must not be vsed, as a market or faier $(1582, \mathrm{~B} 5 \mathrm{r})$

49) Both speech and silence are things commendable (1687, A8v)

50) Not enuieng, but forbearing, with loue and patience $(1582, \mathrm{C} 1 \mathrm{v})$ 
51) Be not desirous to receiue, his Ox, or Ass, or any Beast (1687, C3r)

Figure 8. Binomials in The Schoole according to semantic relationship (percentages)

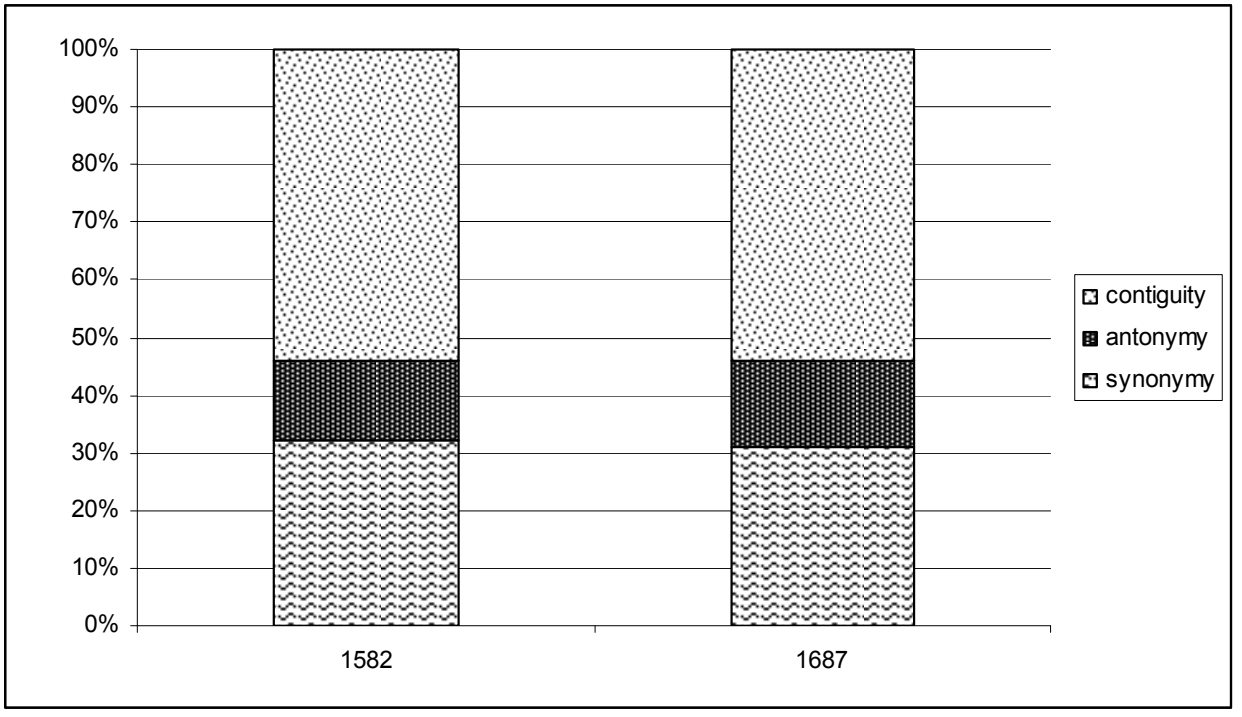

52) For Cato doth saie, that in old or yoong, The first step of vertue, is to bridle the toong $(1582, \mathrm{~B} 3 \mathrm{r})$

53) For Cato doth say that in old and young, the first step of vertue is to bridle the tongue $(1687, \mathrm{~B} 1 \mathrm{r})$

54) O Lorde preserue in peace and health, Our gratious Queene Elizabeth (1582, D3r)

55) O Lord preserve in peace and wealth.

Our noble King, and send him health (1687, C6v)

56) I am thy Lord omnipotent, Whome thou must loue, obey $\&$ feare $(1582, \mathrm{C} 8 \mathrm{v})$

57) I am the Lord omnipotent, whom thou must serve, obey, and fear $(1687, \mathrm{C} 1 \mathrm{v})$ 
The binomials in The Schoole are rarely subject to important editorial modifications, but several instances of structural or lexical replacements can be identified. Whereas replacing or with and in example 53 (cp. example 52), does not seem to affect the text stylistically, some lexical changes may aim at stylistic enhancements. For example, the replacement of health with wealth in the first line in example 55 (cp. example 54) and the introduction of health in the second line improve the rhyme. In other cases, modifications may be due to the personal views of the editor, without any clear stylistic enhancement, as in the change of loue for serve in example 57 (cp. example 56), perhaps reflecting the movement from the gentle Renaissance humanism to the seventeenthcentury emphasis on duty and responsibility.

\section{Conclusions}

"Despise not counsell, but rebuke follie. \# If thou wilt be counted, vertuous \& holie" (1582, A1r). This maxim in the title page of The Schoole, used as the motto of the book, encapsulates and announces some of the most important stylistic features of the text, including the use of the second person singular pronoun, of the imperative construction, and of syntactically and semantically parallel structures such as binomial phrases. These features as well as acronyms, rhymes, stress patterns, periphrastic DO, and typographic devices, including mainly the typeface variation and the layout of the page, are employed in order to enhance the attractiveness, persuasiveness, and mnemonic qualities of the text. Moreover, some of these devices, especially the frequent second person pronoun forms and periphrastic DO, make the style of the book involved and personalised, imitating the characteristics of oral communication and thus creating an ambiance of emotional closeness found in the relationship between the master and the pupil.

It is noteworthy that few changes are recorded between the editions as regards the choice of stylistic devices studied here. This consistency can be motivated by the combined requirements of the register, genre, and text type as well as the target audience of the book. More research is needed to verify if the linguistic and extra-linguistic devices characterising the book under analysis are typical of other manuals of good manners produced in the Early Modern English period. Nevertheless, in the case of The Schoole, they contribute together to the success of the book as the final product. This success is proved by the popularity of the manual, which was re-edited at least eleven times. 


\section{REFERENCES}

\section{PRIMARY SOURCES}

Early English Books Online. Available at: http://wwwlib.umi.com/eebo/ (last accessed on 23 February 2015).

Seager (Segar) [Francis]. 1557. The schoole of Uertue, and booke of good Nourture for chyldren, and youth to learne theyr dutie by. Newely perused, corrected, and augmented by the fyrst Auctour. F. S With a briefe declaration of the dutie of eche degree. London: Wyllyam Seares.

Seager (Segar) [Francis] \& Robert Crowley. 1582. The Schoole of Vertue and booke of good nurture, teaching children and youth their duties. Newlie pervsed, corrected, and augmented. Herevnto is added a briefe declaration of the dutie of ech degree: Also certaine Praiers and Graces compiled by R. C. London: H. Denham.

Seager (Segar) [Francis] \& Robert Crowley. 1593. The Schoole of Vertue, \& Booke of good Nurture, teaching children \& youth their duties. Newly perused, corrected and augmented... London: [John Charlewood for] Richard Iones.

Seager (Segar) [Francis] \& Robert Crowley. 1621. The Schoole of Vertue, and Booke of good Nurture teaching Children and Youth their duties. Newly perused, corrected and amended... London: G. E. for T. P. and I. W.

Seager (Segar) [Francis] \& Robert Crowley. [1626]. The Schoole of Vertue, and Booke of good Nurture, teaching Children and Youth their duties. Newly perused, corrected, and amended... London: M. Flesher for Robert Bird.

Seager (Segar) [Francis] \& Robert Crowley. [c. 1660]. The Schoole of Vertue, and Booke of good Nurture, teaching Children and Youth their duties. Newly perused, corrected, and amended... London: M. Flesher for Iohn Wright.

Seager (Segar) [Francis] \& Robert Crowley. [1670]. The School of Vertue, and Book of good Nurture, teaching Children and Youth their Duties. Newly perused, corrected and amended... London: E. Crowch for J. Wright.

Seager (Segar) [Francis] \& Robert Crowley. 1677. The School of Vertue. And Book of Good Nurture; teaching Children and Youth their Duties. Newly perused, corrected and amended... London: for J. Wright.

Seager (Segar) [Francis] \& Robert Crowley. 1687. The School of Vertue. And Book of Good Nurture; teaching Children and Youth their Duties. Newly perused, corrected and amended... London: for M. W. and George Conyers.

\section{SECONDARY SOURCES}

Adamson, Sylvia. 1999. Literary language. In Roger Lass (ed.), The Cambridge history of the English language. Volume III: 1476-1776, 539-653. Cambridge: Cambridge University Press.

Bhatia, Vijai. 1994. Cognitive structuring in legislative provisions. In John Gibbons (ed.), Language and the law, 136-155. London: Longman.

Bringhurst, Robert. 2008. The elements of typographic style. Vancouver: Hartley and Marks. 
Claridge, Claudia 2012. Linguistic levels: Styles, registers, genres, text types. In Alexander Bergs \& Laurel J. Brinton (eds.), English historical linguistics: An international handbook, 237-253. Berlin: Mouton de Gruyter.

Diller, Hans-Jürgen. 1998. Stylistics: Linguistic and textual. European Journal of English Studies 2.2. $155-174$.

Diller, Hans-Jürgen. 2001. Genre in linguistic and related discourses. In Hans-Jürgen Diller \& Manfred Görlach (eds.), Towards a history of English as a history of genres, 3-43. Heidelberg: Winter.

Griffith, Mark. 2016. The language and meaning of the College motto. Available at: https://www.new.ox.ac.uk/sites/default/files/1NCN1\%20Griffith-Manners.pdf (last accessed on 12 March 2016).

Gustafsson, Marita. 1984. The syntactic features of binomial expression in legal English. Text 4.1-3. 123-141.

Kopaczyk, Joanna. 2009. (Multi-word) units of meaning in 16th-century legal Scots. In R.W. McConchie, Jukka Tyrkkö \& Alpo Honkapohja (eds.), Selected proceedings of the 2008 Symposium on New Approaches in English Historical Lexis (Hel-Lex 2), 88-95. Sommerville, MA: Cascadilla Proceedings Project.

Kopaczyk, Joanna. 2013. The legal language of Scottish burghs. Standardization and lexical bundles (1380-1560). Oxford: Oxford University Press.

Kopaczyk, Joanna \& Hans Sauer. Forthcoming. Introduction: Defining and exploring binomials. In Joanna Kopaczyk \& Hans Sauer (eds.), Binomials in the history of English: Fixed and flexible. Cambridge: Cambridge University Press.

Kristjánsson, Kristján. 2007. Aristotle, emotions, and education. Aldershot: Ashgate Publishing.

Leece, Jonathan. 2011. An unexpected audience: Manner manuals in Renaissance Europe. The Forum: Cal Poly's Journal of History. 3.1, article 11. Available at: http://digitalcommons.calpoly.edu/forum/vol3/iss1/11 (last accessed on 24 February 2015).

Lutz, Angelika. 1998. The interplay of external and internal factors in morphological restructuring: The case of you. In Jacek Fisiak \& Marcin Krygier (eds.), Advances in English historical linguistics, 189-210. Berlin: Mouton de Gruyter.

Malkiel, Yakov. 1959. Studies in irreversible binomials. Lingua 8: 113-160.

Moessner, Lilo. 2012. Early Modern English: Standardization. In Alexander Bergs \& Laurel J. Brinton (eds.), English historical linguistics: An international handbook, 698-714. Berlin: Mouton de Gruyter.

Mollin, Sandra. 2012. Revisiting binomial order in English: Ordering constraints and reversibility. English Language and Linguistics 16.1. 81-103.

Mollin, Sandra. 2013. Pathways of change in the diachronic development of binomial reversibility in Late American English. Journal of English Linguistics 41. 168-203.

Nevalainen, Terttu. 1999. Early Modern English lexis and semantics. In Roger Lass (ed.), The Cambridge history of the English language. Volume III: 1476-1776, 332-458. Cambridge: Cambridge University Press.

Rissanen, Matti. 1999. Syntax. In Roger Lass (ed.), The Cambridge history of the English language. Volume III: 1476-1776, 187-331. Cambridge: Cambridge University Press.

Rutkowska, Hanna. 2013. Orthographic systems in thirteen editions of the Kalender of Shepherdes (1506-1656). Frankfurt am Main: Peter Lang. 
Rutkowska, Hanna. 2016. Orthographic regularization in Early Modern English printed books: Grapheme distribution and vowel length indication. In Cinzia Russi (ed.), Current trends in historical sociolinguistics, 165-193. Berlin: Mouton de Gruyter.

Rutkowska, Hanna. Forthcoming. Binomials in several editions of the Kalender of Shepherdes, an Early Modern English almanac. In Joanna Kopaczyk \& Hans Sauer (eds.), Binomials in the history of English: Fixed and flexible. Cambridge: Cambridge University Press.

Stribley, Miriam. 1987. The calligraphy source book: The essential reference for all calligraphers. London: Quarto Publishing. 